\title{
Introduction and Evaluation of the Notice Boards Designed for Pre-school Children and Their Parents within the Framework of "Media Literacy" Theme
}

\author{
Belgin Arslan Cansever ${ }^{1, *} \&$ Gamze Bilir Seyhan ${ }^{1}$ \\ ${ }^{1}$ Faculty of Education, Department of Primary Education, Ege University, Izmir, Turkey \\ *Corresponding author: Faculty of Education, Department of Primary Education, Ege University, Izmir, Turkey. Tel: \\ 90-232-311-3156. E-mail: belginarslan6@hotmail.com
}

The part including the pilot application of this article was presented as a verbal statement in the "Congress of International Pre-school Education: Experiences of Interdisciplinary Contributions, Theories and Practices" held on 25-27 September, 2014 at İstanbul Kültür University.

Received: November 2, 2014

Accepted: January 16, 2015 Online Published: January 21, 2015

doi:10.5430/wje.v5n1p82

URL: http://dx.doi.org/10.5430/wje.v5n1p82

\begin{abstract}
The aim of this study was to raise the awareness of pre-school teacher candidates within the framework of media literacy the importance of which has been noticed recently in Turkey and which has attracted attention of academic circles as a research topic. In addition, by providing opportunities for pre-school candidates to design materials on this topic, it also aimed to help them practice what they know and internalize the information they would obtain on media literacy. In this regard, the article introduces the notice board practices of media literacy theme performed by teacher candidates for pre-school students and their parents. Teacher candidates made their own choices on designing notice boards either for children or for their parents. Encouraging candidates to design such notice boards and to use them in training and then in their professional life is extremely important for them both to discover their own creativity and to develop their hand skills. Moreover, dealing with the media literacy theme and expecting them to develop materials by informing the candidates on this issue is a step taken towards raising the awareness of teacher candidates who will educate future generations. From this point of view, it could be recommended to provide practices on board and material development and use within the framework of media literacy theme through in-service seminars for teachers currently continuing their professional life; and to share functional teaching materials among teachers on various platforms (conferences, congress, workshops etc.).
\end{abstract}

Keywords: media literacy; preschool teacher candidates; board designs

\section{Introduction}

Teachers have a significant impact on the development of a society. They shape the society by working with children. In this way, a future with a high level of welfare could be constituted. To be able to become an effective and qualified teacher, they are supposed to improve themselves in their undergraduate years and professional years, qualitatively. According to Gültekin (2002), teachers have an important role in education system and it is important that a qualified teacher training and education could be provided eligible teacher education programs. With the help of these education programs, teachers with competencies could be trianed and the quality of the education could be enhanced. It is necessary to place importance to teacher competencies if a qualified education is required in a class. Teacher competencies, including knowledge, skills, and attitudes which teachers possess, are categorized into three different sections (MEB, 2006). These sections are professional teaching knowledge, pedagogical content knowledge, and general knowledge (Lunenberg, 2002; Sünbül, 2001). One of the subfields of professional teaching knowledge is learning and teaching process competency including planning lesson, preparing environment and activities, diversification of teaching, time management, behavior management, and material development (Yavuz Konokman \& Yanpar Yelken, 2013). These competencies are required to create an environment in which effective learning and teaching can be maintained. Among these competencies, material development are used to create materials which 
improve the quality of learning and teach children, permanently.

In teacher training programs, teacher candidates take courses related to material development. One of these courses is "Instructional Technology and Material Development" and teacher candidates find an opportunity to learn the importance of materials in education, and how to create materials for teaching and learning, and to develop their own materials. Herewith, they experience material development process, they can use this experience when it is needed in their professional teaching life. To be able to develop effective materials, teacher candidates are supposed to know the functions of them in teaching, preparation principles, types, advantages, and limitations of them (Gündüz \& Odabaş1, 2004). Well-qualified materials can be used for different purposes as attention getting, giving the knowledge, giving feedback, providing participation (Akkoyunlu, 2002), motivating students, facilitating learning and teaching (Şahin \& Yildırım, 1999), creating a pleasant and significant learning environment (Demirel, 2002), and materialising the abstract terms, concepts, and subjects (Karataş \& Yapıc1, 2006).

It is important that teacher candidates know some points to consider when developing the materials. These points are being simple and understandable, fitting for purposes, choosing appropriate visuals, being age-appropriate, reflecting real life, being accessible to each students and durable for several usages (Yanpar-Şahin \& Yıldırım, 1999). With the help of materials, individuality in the classroom are taken into consideration. Because appropriate and qualified materials appeal to all students with different learning styles such as visual, auditory, and tactile (Karataş \& Yapıcı, 2006).

Using materials in education is very critical and important in early childhood education. The reason is that children do not have capacity to understand and learn abstract subjects, terms, and concepts, in this period, developmentally. Preschool teacher candidates are supposed to know developmental chracteristics of children and regulate teaching and learning processes in terms of these characteristics. For providing an effective preschool education, the physical environment of classroom matters for all people who are related to the education in that class. In preschool period, children have a desire to learn, a curiosity to everything, and an interest in new around them. If children are answered phsically and psychologically, their development and learning proceed, positively. In child life, developing age-appropriate behaviors depend on responsiveness of stimulus to children's requirements. A preschool class with properly prepared environment and qualified materials is for children's healthy, reliable, and whole development (Çelik \& Kök, 2007). In preschool period, learning by doing is a very significant way for children since they learn easier if they do hear, see, touch, smell, hold, and feel. In other words, it can be said that the best learning way is experience. According to Montessori, an environment, providing concrete experience to children and including well-desinged materials, ensures an effective learning (Berk, 2006). In Turkish preschool classrooms, teachers are supposed to prosper their educational experiences with the help of using different environments, activities, and materials (MEB, 2013). In this context, preschool teacher candidates should learn how to design classroom and develop materials in order to provide a rich learning opportunities and give chances to children for choosing which materials they want (Kostelnik, Soderman, \& Whiren, 2004).

\subsection{Media Literacy and Its Importance in the Pre-school Period}

Today, children are surrounded by traditional and new media tools. Educational paradigm of the $21^{\text {st }}$ century aims at raising individuals that have the information, skills and competence to know the media in all aspects and to use it in a certain educational framework, in other words, raising media literate individuals (Arslan Cansever, 2013a). Media literacy can be defined as "an individual's making use of media tools and knowing how to use them, receiving, perceiving, filtering the messages from 'traditional (newspapers, magazines, radio, television etc.) and 'new' (internet, mobile phones, game consoles etc.) media tools through the conscious, interpreting and evaluating them with a critical point of view and transferring (verbal or written) them to another individual (Aslan, Aslan, \& Arslan Cansever, 2012: 47). In the information society, individuals are expected to evaluate and analyze what they read, listen to or see on the media with a critical point of view instead of receiving the message in a passive way without questioning it (Arslan Cansever, 2013b). Kellner and Share, (2005) state that media literacy has recently been dealt with in education and that it is a concept which is rarely addressed and discussed in teacher training. In this regard, it is important that preschool teacher candidates are aware of the media around them, develop a critical understanding of it, are sensitive to the real messages of the media, use techniques for creating media products for education with the help of media literacy. By doing so, they will be equipped with the media literacy and a good model for children in their future preschool classrooms.

Board using in the pre-school period is one of the materials used in preschool classrooms with various purposes. The boards can be used as activity boards, notice/communication boards, and informing boards. The activitiy boards are used to exhibit children's works, and hang on materials used in the activities. The boards taking part in the 
classrooms can be seen as activity boards. The notice/communication boards are used to communicate with parents and to make an announcement about children, daily plan, trip/theatre etc. programs, and general operation of the preschool. The informing boards as the last kind of boards are prepared for giving information to target audiences which can be divided into two different groups as children and parents.

The informing boards for children are supposed to be clear, colorful, interesting, appealing to children, focusing on only one concept/subject. With the help of the boards, teacher can take children's attention, inform them about the concept or subject, facilitate their learning, raise awareness of the concept or subject, remind the previous learning. Teachers can create and use the informing boards for parents as a way of parent involvement (Tezel Şahin \& Özyürek, 2011). By means of the informing boards with an interesting heading for parents, teachers give information about their children, issues related to child development and learning (Puckett \& Diffily, 2004, as cited in İlgar \& Topaç, 2013), factors affecting on children, samples of activities which can be done outside the school. In stead of formal information sheet for parents, the informing boards are more interesting, remarkable, and effective way of involving parents in their children's education. It can be thought that the given information via the informing boards are more memorable for parents. In the light of all these information, preschool teachers candidates are supposed to know how to prepare boards for children and parents for using in their future classrooms.

Instructional Technologies and Material Development course is a compulsory course in the curriculum of Preschool Education Program. With the help of this course, teacher candidates have an opportunity to put theory into practice. After taking this course, teacher candidates are expected to know general knowledge about instructional technologies. Besides this, it is thought that they are able to develop materials for their teaching process. In the light of these information, media literacy concept was thought as an appropriate subject used in notice boards for giving information to children and parents because media literacy is an unexamined subject in preschool period, in detail. In this context, preschool teacher candidates were expected to prepare notice boards related to media literacy concept in Instructional Technologies and Material Development course. The purpose of the present study is to raise the awareness of pre-school teacher candidates within the framework of media literacy, emphasize the importance of material use in education, and describe the informing boards about the media literacy as a teaching material developed by preschool teacher candidates within the scope of the course Instructional Technologies and Material Development. In this regard, the article introduces the notice board practices of media literacy theme performed by teacher candidates for preschool children and their parents. It is thought that this study will contribute to the subject of media literacy in preschool period, attract attention to the importance of material development in undergraduate years as teacher candidates, and constitute an example for future instructing lessons and conducting researches.

\section{Method}

This is a qualitative study and document analysis was used for gathering the data. In this study, document analysis is used as data collection method because it includes analyzing materials related to the research subject. Students' homework and exams, lesson plans, student and teacher books are some of the documents used in education (Yıldırım \& Şimşek, 2008). For this study, the informing boards about the media literacy as a teaching material developed by preschool teacher candidates within the scope of the course Instructional Technologies and Material Development are used as materials to be analyzed.

\subsection{Data Gathering Process}

In the course Instructional Technologies and Material Development, the teacher candidates who designed the informing boards were first informed about the importance of board designing in pre-school education, board types and preparation styles. Later, they were included in training on media literacy, which covered 8 hours of classes during 2 weeks. In the planning stage, the focus was on the necessity that the boards to be designed should be attractive, simple, and understandable and make the subject concrete. The informing boards were designed in a way that their stylistic properties would coincide with the information given on the boards. For children, informing boards were prepared, which aimed to introduce media tools considering the developmental characteristics of children aged 3-6. Informing board designs can be seen as a part of learning by doing and experience for teacher candidates. These informing boards were used as the data for this study.

\subsection{Data Analysis}

To analyze the informing boards, some criteria were determined with the help of literature by the researchers. These criteria were durability, reusability, portability, functionality, creativity, and eligibility for designing components. While the durability is about materials' long term utilization, the reusability is about materials' utilization for 
different purposes. In this way, designed materials can be used for many times in a classroom. Besides, portability is that materials can be carried easily and they may be foldable. Another criterion is related to functionality. According to functionality, materials should be related to the subject. For example, the materials should be related to media literacy in this study. Another criterion is about creativity. The students are expected to be creative when developing materials so creative and original materials can be revealed. Last criterion used for analyzing the informing boards is about eligibility for designing components. All the informing boards developed in the course Instructional Technologies and Material Development were analyzed in terms of these criteria and a score were given to each material. At the end of this evaluation process, the fourteen materials with the highest scores were chosen for this study and they were presented in the sample applications part of the study.

\section{Sample Applications}

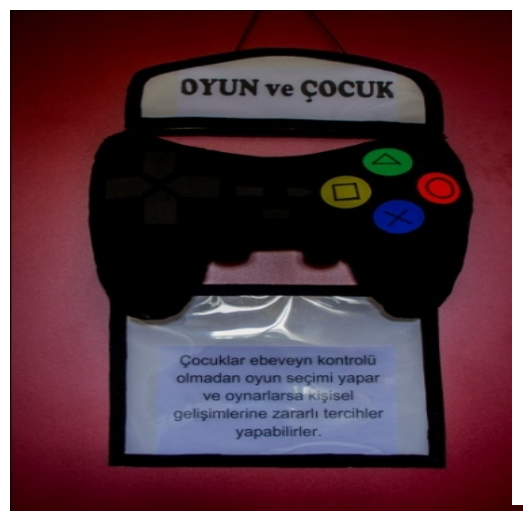

The aim of the "Games and Children Board" designed for parents is to share the effects of the games played on computer or game consoles, which have been found by several studies (Cherney \& London, 2006; Christakis, Ebel, Rivara, \& Zimmerman, 2004; Haugland, 1992; Li \& Atkins, 2004; Mendoza, Zimmerman, \& Christakis, 2007; Vilozni et al., 2005) to have an important place in children's world, on children's personal development with parents. The board also gives parents some information concerning what they need to do on this issue. The part including the information and the title were designed in a changeable way.

Picture 1. Games and Children Parents' Informing Board

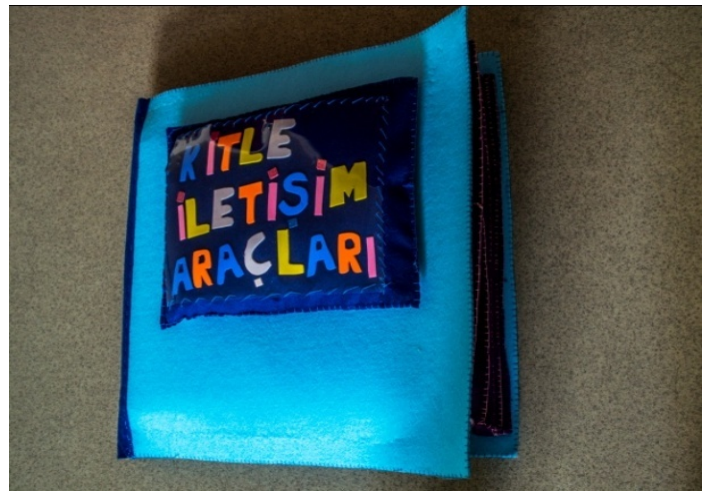

Picture 2. Mass Media Book Cover-

Children's Informing Board

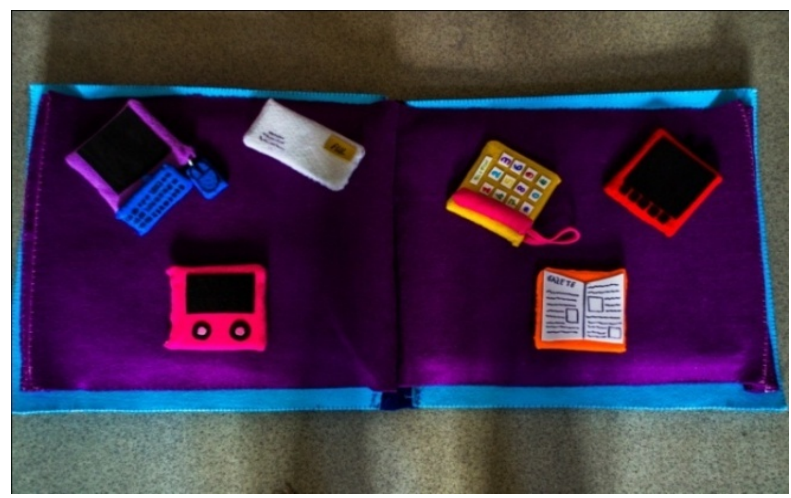

Picture 3. Mass Media Book Content-

Children's Informing Board

The aim of the different board design called "Mass Media" designed like book is to present both traditional and new media tools to pre-school children in a book, which is defined as a traditional media tool. Picture 3 shows the communication tools in the book. The miniature tools (phone, computer, radio, newspaper etc.) designed in a removable way enable the child to learn while playing games on one hand, and make the learning more permanent by activating the sense of touch on the other. 
The target audience of the "Media Tools" board designed to put up on the door for parents coming to pick their children up from school is parents. On this board, which was designed in a changeable way, media tools like books, newspapers and television were introduced for the first week. The aim of this board is to raise the awareness of parents on how and how long children can make use of media tools according to their age groups.

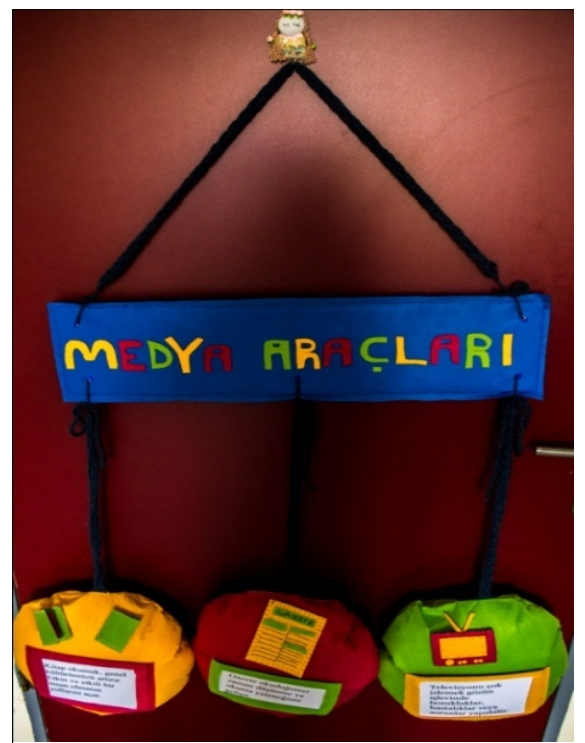

Picture 4. Media Tools Door Board Parents' Informing Board

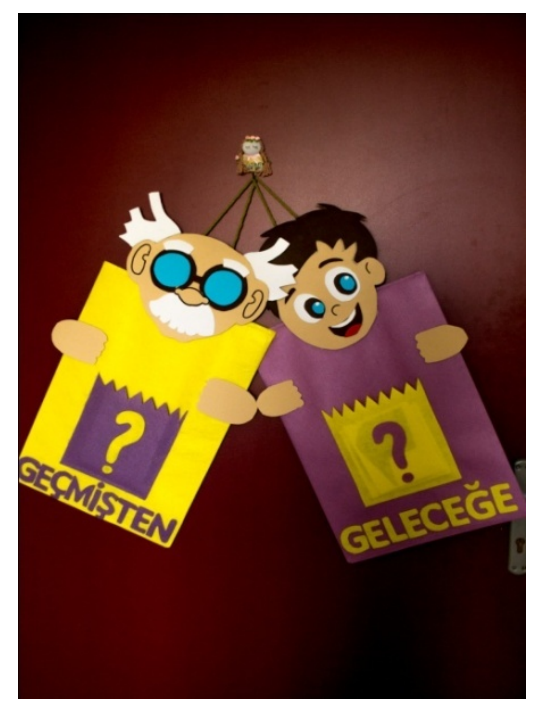

On "the From Past to Future" board, 'traditional media tools' are presented under the grandfather picture and 'new media tools' under the child picture. Different media tools are placed in the pockets with the question mark and it can be used by the teacher as an educational game material in the class. The teacher asks children to classify the media tools on the pictures s/he shows and they play a simple game with the help of the board by putting them into the pockets.

Picture 5. From Past to Future Children's Informing Board

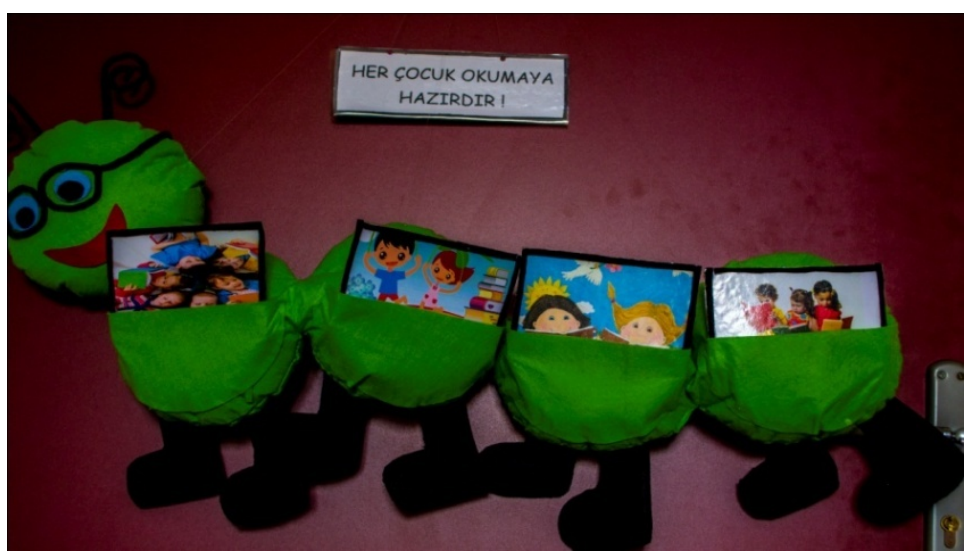

Picture 6. Caterpillar Board - Children’s Informing Board 
The "Caterpillar Board" aims to infuse children with a love for reading. This children's board, which will be used in the class of on the door for a week, consists of pictures concerning reading books. As a part of reading activities, the teacher may ask children's opinions about these pictures and start bringing the love for books in children as of early ages. The board was designed in a way that allows for a different theme each week. The second week topic and message of the board was designed as another media tool.

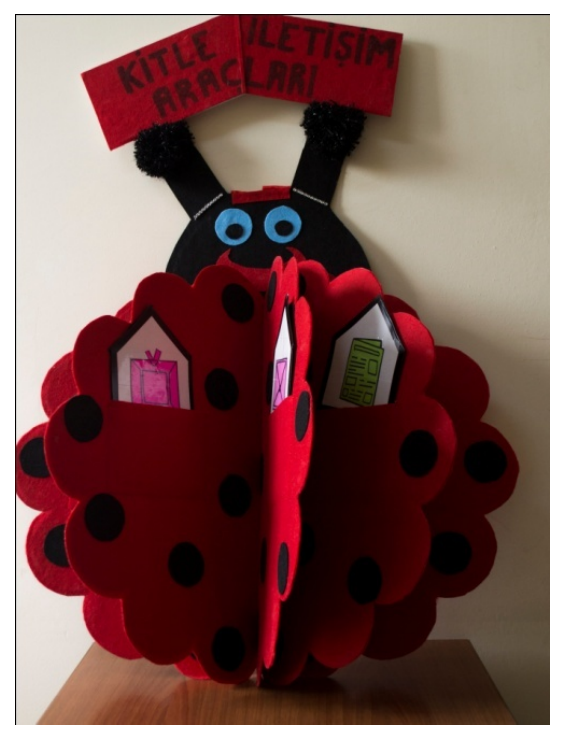

The "Ladybug" board, which was developed with the inspiration from children's love for animals, can be used either by hanging up or in a horizontal position on the desk. There is a small bag on each wing of the ladybug and picture of different media tolls are attached in these bags. The teacher draws these pictures and tells students the name of the media tool and things to be considered while using these tools. After this use, on a different day, the teacher can have the children play a game by asking some questions about the points they addressed before and making the children find the correct media tool.

Picture 7. Ladybug Children's Informing Board

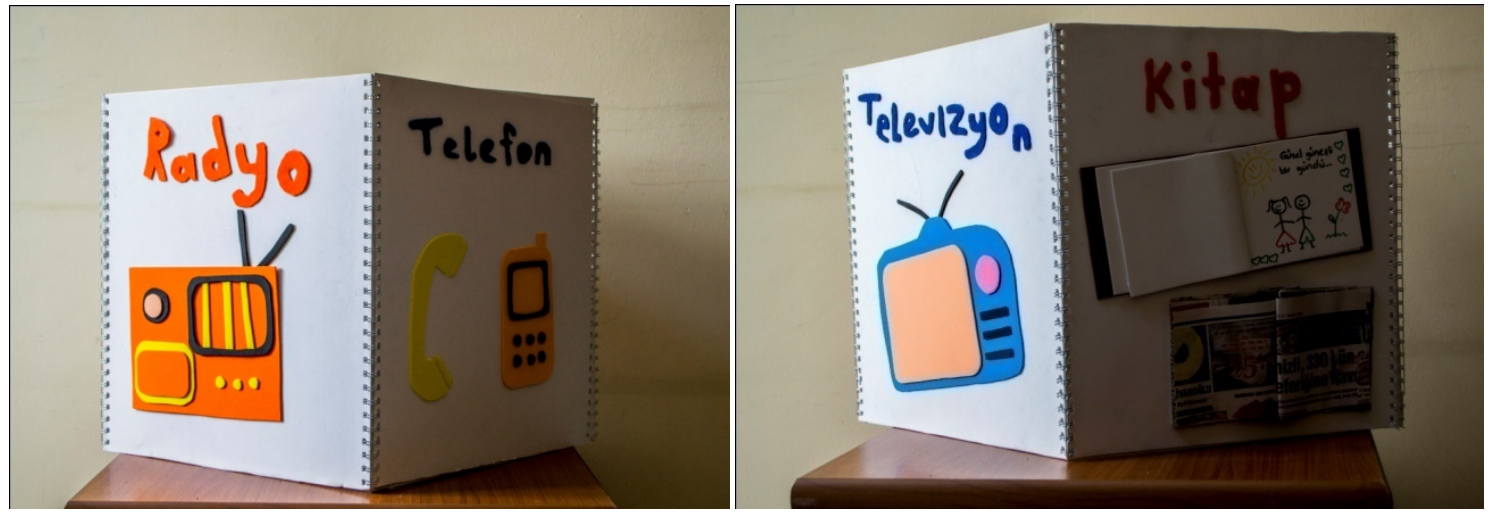

Picture 8-9. Media Tools Cube Children's Informing Board

In Pictures 8 and 9 is an informing board designed as a cube in order to introduce mass media tools to children. There is a different communication tool on each face of the cube. After being used as a teaching material by the teacher, this board can be put in a corner of the classroom, which can held children develop their visual memory. 

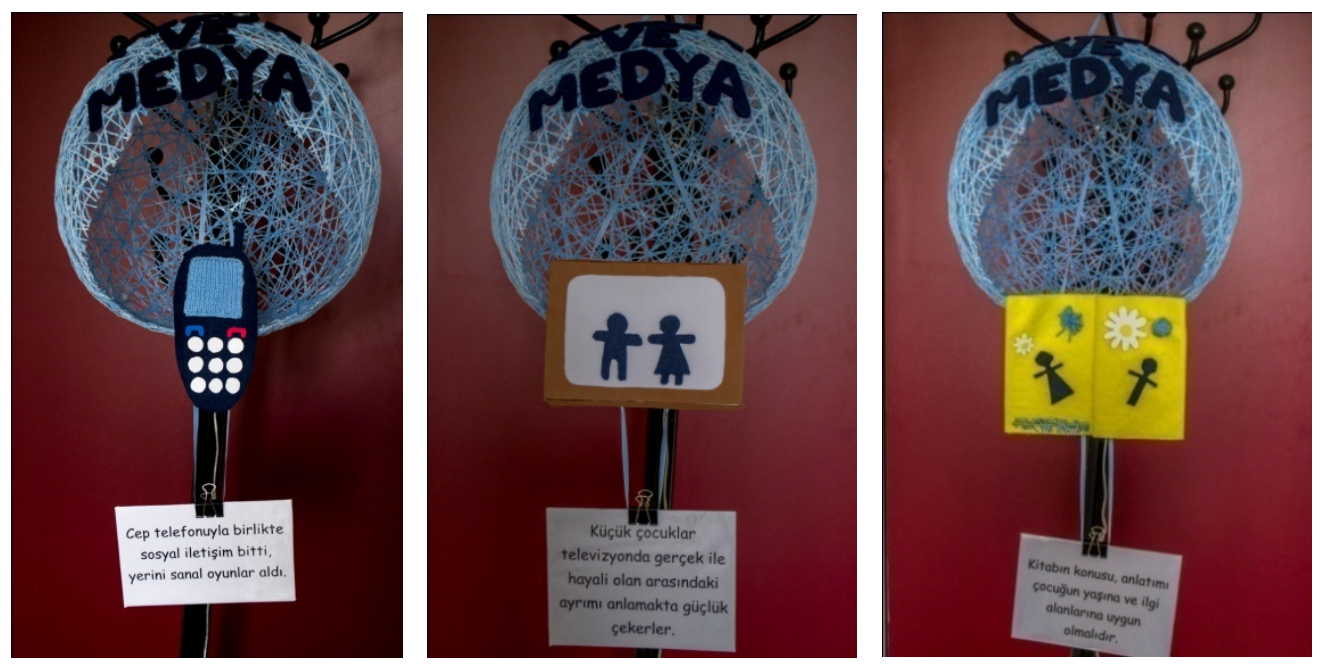

Picture 10-11-12. Child and Media Globe Parents' Informing Board

The "Child and Media" Parents' informing board, which catches attention with its different designs, provide information to parents on the effects of media tools on child development and also offers advice on using these tools consciously. This board, on which the information and media tools can be changed, aims at raising the awareness of parents of mobile phones, television and book choice. The information and models of media tools can be changed with quite simple techniques.

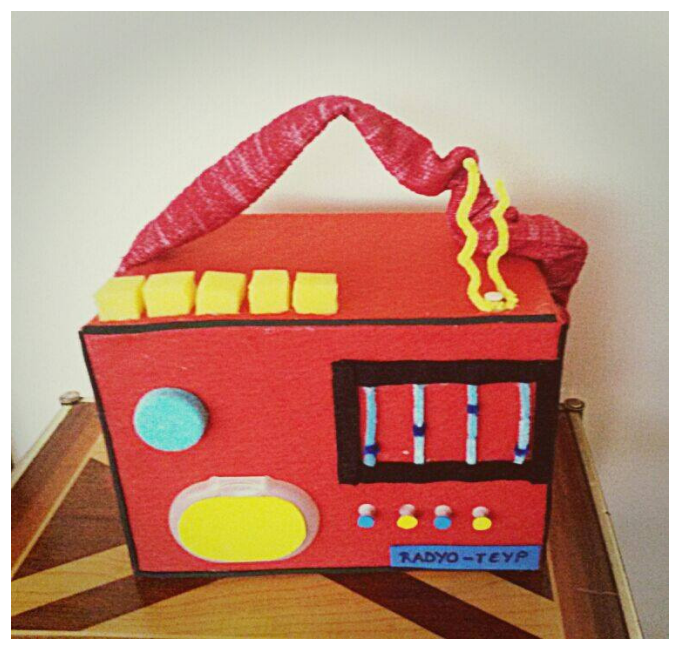

"Radio-Tape" design children's board aims at introducing a nostalgic communication tool, the radio, to children. Some recent studies (Arslan Cansever, 2013a; Berman, 2008; Jumani, 2009; Wartella \& Jennings, 2000) have shown that the place of the radio has become smaller in the $21^{\text {st }}$ century world. In this respect, the model radio board may be a way of increasing the child's awareness of listening to the radio.

Picture 13. Model Radio Children's Notice Board 


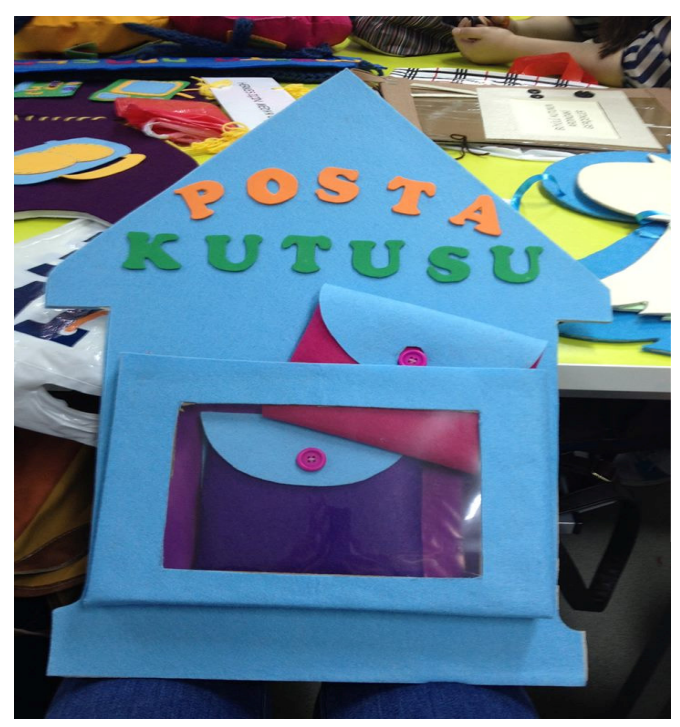

The aim of the "Mailbox" board is to introduce children "the letter", which is a traditional means of media replaced by different communication ways today. Letters can be written with children to people they want and be put into this mailbox, which can be hung on the classroom wall or door, and therefore the child learns communication through "letters" as of pre-school period.

Picture 14. Model Mailbox Children’s Informing Board

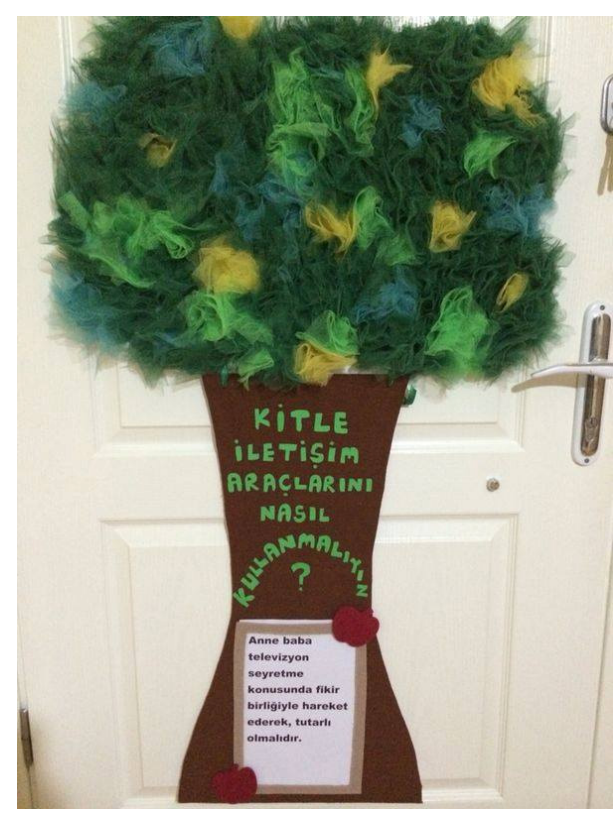

This tree shaped parents' notice board designed as a door board aims mainly at informing parents on the conscious use of mass media tools in general. The information tags placed on the root of the tree board can be changed and on each tag, information about a different media tool is provided.

Picture 15. Tree Board Parents' Informing Board 
The aim of the butterfly board designed as a parents' informing board is to inform parents about media literacy and to increase their awareness. The target audience of this board, which can be put up on the school walls is mainly the parents who come school to collect their children and have limited time. This board aims at giving parents short, essential, clear and understandable messages about the topic.

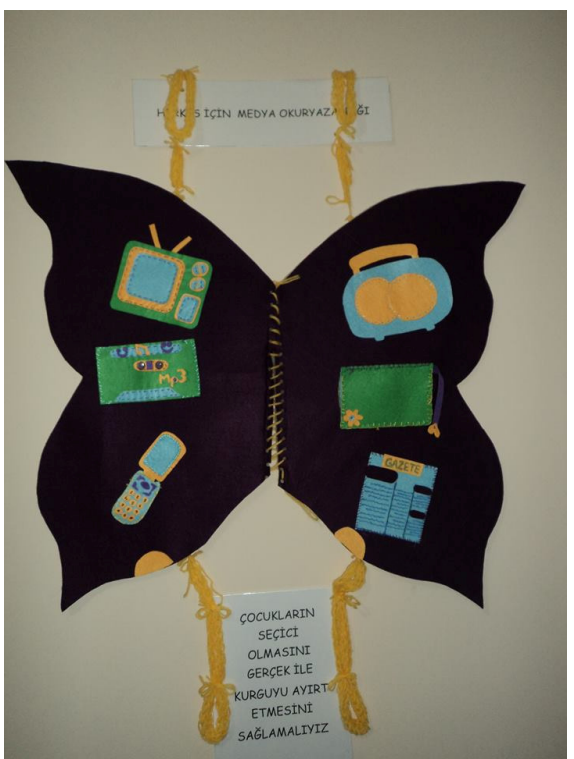

Picture 16. Butterfly Board Parents’ Informing Board

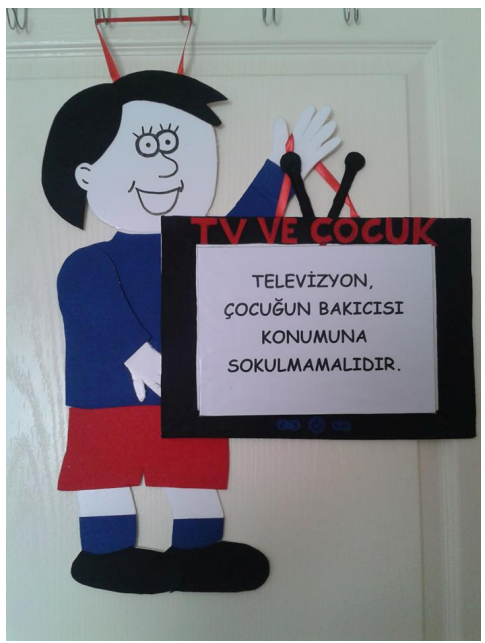

The focus of the "Television and Child" board is the use of television- which has been verified to have an important place in children's world by many studies (Aran \& Rodrigo, 2013; Arslan Cansever, 2013a; Cho \& Yoo, 2014; Haines et al., 2013; Nathanson, Sharp, Alade, Rasmussen, \& Christy, 2013; Vega \& Lafaurie, 2013). In this board designed for parents, information is provided on the length of time to use television, program types to be chosen and watching with a parent etc. according to children's age.

Picture 17. "Television and Children” Parents' Notice Board

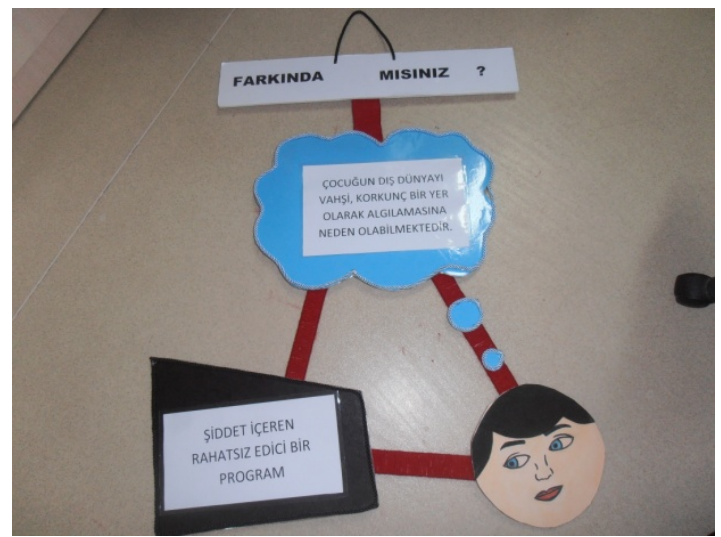

The parents' informing board named "Are you aware?" aims to guide parents to think about the use of media tools. The first week topic of the board, on which the information can be changed, is about the possible effects of any television program including violence watched by children on their mental world. This board gives parents the message that they should look at media tools with a critical point of view for their children's physical and mental health.

Picture 18. Are You Aware? Parents’ Informing Board 


\section{Discussion}

Teacher candidates are educated with competencies and skills in universities in order to become effective teachers. Hereby, they are able to educate children and shape future of their society. In this context, teacher training programs have an important role for preparing teacher candidates for their professional teaching lives. Teacher training provides teacher candidates learn general knowledge about their profession field, have chances for teaching practices, so put the theory into the practice. A qualified teacher candidate is able to become an expert in the profession field and know how to educate students with different physical arrangements in classroom, activities, and materials to catch students' attention, facilitate learning, and make learning permanent. A 21st-century teacher is expected to use technology in the educational environment, and to design and use those teaching materials that can integrate their professional knowledge with practice so that they can turn abstract information into something concrete (Arslan Cansever, 2014). To help teacher candidates meet this expectation, Instructional Technologies and Material Development course is a way of integration technology with the classroom. With this course, teacher candidates learn use materials in education and how to create their own materials related to the subject which they will teach in their classrooms. Thus, they learn by doing, have an opportunity to combine theoretical knowledge and practice, and prelude teaching life.

Materials used in education enrich learning environment, support individualized learning, and make activities more pleasant (Wardle, 2011), take children's attention to the subject which they will teach (Kol, 2012). The teacher training programs teach teacher candidates how to develop materials by using different instructional technologies, and assess existing materials in the classrooms. Especially in preschool education, teachers' should choose, develop, and use age-appropriate and developmentally appropriate materials for children (Dinç, 2011). Besides, using media literacy theme in the boards introducing in this study have an importance for teacher candidates. Because, they have obtained general knowledge about media literacy, have been given a chance to examine the media around them more consciously, and have been involved in this concept to create a material.

With the help of this study, the media literacy subject was practiced with preschool teacher candidates, and they had a chance to develop effective materials for children and parents by using media literacy subject. When examined sample applications in the present study, it can be said that all the materials have a common purpose. This purpose is to make invisible into visible, abstract into concrete, and incomprehensible into comprehensible for children or their parents. In this way, children and parent can be incorporated into children's learning and development because the boards can be seen a bridge between children, parents, and classroom. According to this study, all the presented materials fulfil the criteria, which were durability, reusability, portability, functionality, creativity, and eligibility for designing components. Besides this, it can be said that the other materials, developed by preschool teacher candidate in Instructional Technologies and Material Development course, met the criteria, satiably. Besides this, the importance of material use in education was emphasized during the lessons. It can be made a deduction about that preschool teacher candidates have learnt how to develop an effective material for education, and also have gained awareness of media literacy subject in preschool period because their materials were functional including materials' being related to the subject. All these conclusions have indicated that the study has reached its purposes.

In the light of all these information, it is recommended that Instructional Technologies and Material Development, four credits at the Department of Preschool Education in one term, should be conducted during two terms so that teacher candidates will have the opportunity to plan and create more materials. Furthermore, teacher candidates should be encouraged to develop and use materials in their university education and future professional life. In addition, process of creating boards as instructional material can be seen as a part of learning by doing experience. It is important that teacher candidates create these boards by using their creativity and developing their hand skills and use them in their teaching practices. In addition to all these, using media literacy theme in these boards and informing teacher candidates about this subject are important steps for raising awareness of them about this subject. It can be concluded that using informing boards as an instructional material in the preschool classroom is an effective way to give information to children and parents.

\section{References}

Akkoyunlu, B. (2002). Educational technology in Turkey: Past, present and future. Educational Media International, 39(2), 165-174. http://dx.doi.org/10.1080/09523980210155352

Aran, S., \& Rodrigo, M. (2013). The notion of violence in television fiction: Children's interpretation. Comunicar, 20(40), 155-164. http://dx.doi.org/10.3916/C40-2013-03-06 
Arslan Cansever, B. (2013). Material designs in education. The Learning Teacher Magazine, The Learning Teacher Network, 4(1), 3, Sweden, ISSN: 2000-2610.

Arslan Cansever, B. (2013a). Çocukların "Medya" ile "Medya Okuryazarlığı"na İlişkin Algıları, 23 Nisan TRT Uluslararası Çocuk ve Medya Kongresi-II, 16-18 Nisan, İzmir.

Arslan-Cansever, B. (2013b). Turkish teacher candidates' perceptions of the "media literate individual" through metaphors. International Journal of Scientific Research in Education (IJSRE), 6(2), 204-213.

Arslan Cansever, B. (2014). Sample applications from material designs prepared for various primary school classes. International Conference on Primary Education (IOJPE). International Online Journal of Primary Education, $3(2), 14-23$.

Aslan, K., Aslan, N., \& Arslan Cansever, B. (2012). Egitim bilimine giris (Introduction to education). Pegem Akademi, Ankara.

Berk, L. (2006). Child development. Boston, MA: Pearson/Allyn and Bacon.

Berman, S. D. (2008). The return of educational radio? International Review of Research in Open and Distance Learning, 9(2), 1-8.

Cherney, I. D., \& London, K. (2006). Gender-linked differences in the toys, television shows, computer games, and outdoor activities of 5-to-13-year-old children. Sex Roles, 54, 717-726. http://dx.doi.org/10.1007/s11199-006-9037-8

Cho, E., \& Yoo, S. (2014). Effecs of violent television programmes on advertising effectiveness among young children. International Journal of Advertising, 33(3), 557-578. http://dx.doi.org/10.2501/IJA-33-3-557-578

Christakis, D. A., Ebel, B. E., Rivara, F. P., \& Zimmerman, F. J. (2004). Television, video, and computer game usage in children under 11 years of age. The Journal of Pediatrics, 145(5), 652-656. http://dx.doi.org/10.1016/j.jpeds.2004.06.078

Çelik, M., \& Kök, M. (2007). Okulöncesi egitim kurumlarında egitim ortamı ve donanımının önemi. Kazım Karabekir Eğitim Fakültesi Dergisi, 15, 158-170.

Demirel, Ö. (2002). Planlamadan değerlendirmeye öğretme sanatı (From planning to assesing teaching art). Ankara, Pegem A Yayıncilık.

Dinç, B. (2011). Designing quality educational materials for preschool children: Opinions and practices. The International Journal of Learning, 17(10), 469-477.

Gültekin, M. (2002). Eğitim fakülteleri öğretmen yetiştirme programlarının yeniden düzenlenmesi kapsamında ilköğretime öğretmen yetiştirme. Anadolu Üniversitesi Ĕgitim Fakültesi Dergisi, 12(1-2), 49-65.

Gündüz, Ş., \& Odabaşı, F. (2004). Bilgi çağında öğretmen adaylarının eğitiminde öğretim teknolojileri ve materyal geliştirme dersinin önemi. The Turkish Online Journal of Educational Technology - TOJET, 3(1), 43-48.

Haines, J., O’Brien, A., McDonald, J., Goldman, R. E., Evans-Schmidt, M., \& Price, S. et. al. (2013). Television viewing and televisions in bedrooms: Perceptions of racial/ethnic minority parents of young children. Journal of Child and Family Studies, 22, 749-756. http:/dx.doi.org/10.1007/s10826-012-9629-6

Haugland, S. W. (1992). The effect of computer software on preschool children's developmental gains. Journal of Computing in Childhood Education, 3(1), 15-30.

İlgar, Ş., \& Topaç, N. (2013). Okul öncesi öğretmenlerinin okul-aile işbirliğine ilişkin görüşlerinin değerlendirilmesi. Sakarya Üniversitesi Eğitim Fakültesi Dergisi, 26, 93-114.

Jumani, N. B. (2009). Study on role of radio for rural education in Pakistan. Turkish Journal of Distance Education, 10(4), 176-187.

Karataş, S., \& Yapıcı, M. (2006). Öğretim teknolojileri ve materyal geliştirme dersinin işlenişi ve uygulama örnekleri. Afyon Kocatepe Üniversitesi Sosyal Bilimler Dergisi, 8(2), 311-325.

Kellner, D., \& Share, J. (2005). Toward critical media literacy: Core concepts, debates, organizations, and policy. Discorse: Studies in the Cultural Politics of Education, 26(3), 369-386. http://dx.doi.org/10.1080/01596300500200169

Kostelnik, M.J., Soderman, A.K., \& Whiren, A.P. (2004). Developmentally appropriate curriculum (3rd Edition). Ohio: Merril Prentice Hall. 
Kol, S. (2012). Okul öncesi eğitimde teknolojik araç-gereç kullanımına yönelik tutum ölçeği geliştirilmesi. Kastamonu Ĕ̈itim Dergisi, 20(2), 543-554.

Li, X., \& Atkins, M. S. (2004). Early childhood computer experience and cognitive and motor development. Pediatrics, 113(6), 1715-1722.

Lunenberg, M. (2002). Designing a curriculum for teacher educators. European Journal of Teacher Education, 2(3), 264-277. http://dx.doi.org/10.1080/0261976022000044872

MEB (2006). Öğretmenlik mesleği genel yeterlikleri. Öğretmen Yetiştirme ve Eğitimi Genel Müdürlüğü, Ankara.

MEB (2013). Okulöncesi eğitim programı (36-72 aylık çocuklar için) kitabı. Ankara: Milli Eğitim Bakanlı̆̆ı Yayınları.

Mendoza, J. A., Zimmerman, F. J., \& Christakis, D. A. (2007). Television viewing, computer use, obesity, and adiposity in US preschool children. International Journal of Behavioral Nutrition and Physical Activity, 4(44). http://dx.doi.org/10.1186/1479-5868-4-44

Nathanson, A. I., Sharp, M. L., Alade, F., Rasmussen, E. E., \& Christy, K. (2013). The relation between television exposure and theory of mind among preschoolers. Journal of Communication, 63(6), 1088-1108. http://dx.doi.org/10.1111/jcom.12062

Sünbül, A. M. (2001). Bir meslek olarak öğretmenlik: Öğretmenlik mesleğine giriş (Teachership as a profession: Introduction to teaching profession) (Ed. Demirel, Ö. ve Kaya, Z.). Ankara: Pegem A Yayıncıllk.

Şahin T.Y. ve Yıldırım, S. (1999). Öğretim Teknolojileri ve Materyal Geliştirme. Ankara, Anı Yayınevi.

Tezel Şahin, F., \& Özyürek, A. (2011). Anne baba eğitimi ve okul öncesinde aile katılımı (Parent education and parent involvement in preschool). İstanbul: Morpa Yayınları.

Vega, J., \& Lafaurie, A. (2013). A children's observatory of television: "Observar TV", a space for dialogue between children. Comunicar, 20(40), 145-153. http://dx.doi.org/10.3916/C40-2013-03-05

Vilozni, D., Barak, A., Efrati, O., Augarten, A., Springer, C., \& Yahav, Y., et.al. (2005). The role of computer games in measuring spirometry in healthy and "asthmatic" preschool children. Chest Journal, 128(3), 1146-1155. http://dx.doi.org/10.1378/chest.128.3.1146

Wardle, F. (2014). The Role of Technology in Early Childhood Programs. Retrieved from http://www.earlychildhoodnews.com/earlychildhood/article_view.aspx?ArticleID=302, on 10.09.2014

Wartella, E A., \& Jennings, N. (2000). Children and computers: New technology-old concerns. The Future of Children, 10(2), 31-43. http://dx.doi.org/10.2307/1602688

Yanpar-Şahin, T., \& Yıldırım, S. (1999). Öğretim teknolojileri ve materyal geliştirme (Instructional technologies and material development). Ankara: Anı Yayıncılık.

Yavuz Konokman, G., \& Yanpar Yelken, T. (2013). Öğretmen adaylarının öğrenme öğretme süreci alanındaki yeterliklerine ilişkin görüşleri. Mersin Üniversitesi Eğitim Fakültesi Dergisi, 9(1), 175-188.

Yıldırım, A., \& Şimşek, H. (2008). Sosyal bilimlerde nitel araştırma yöntemleri (Qualitative research methods in social sciences). Seçkin, Ankara. 